\title{
Diamond formation in reduced fluids and melts
}

\author{
Alexander G. Sokol, Yury N. Palyanov, Galina A. Palyanova \\ Novosibirsk, Institute of Geology and MineralogySB RAS, sokola@uiggm.nsc.ru
}

In the vicinity of the boundary between lithosphere and astenosphere the value of $f \mathrm{O}_{2}$ in the mantle rocks is estimated at the level of FMQ-4 log units, and equilibrium fluid contains water and methane (Woodland, Koch, 2003). At such low $f \mathrm{O}_{2}$ values carbonates and carbonate melts should be unstable in both eclogitic and peridotitic parageneses (Luth, 1999). The results obtained in (Woodland, Koch, 2003; Rohrbach, 2007) indicate further decrease in redox potential at astenospheric depths. Therefore for the most part of the upper mantle the probable diamond-forming media could be reduced fluids/melts.

Modeling of the diamond formation was performed in the $\mathrm{H}_{2} \mathrm{O}-\mathrm{CH}_{4}-\mathrm{C}$ and $\mathrm{Mg}_{2} \mathrm{SiO}_{4}-\mathrm{H}_{2} \mathrm{O}-\mathrm{CH}_{4}-\mathrm{C}$ systems at $6.3 \mathrm{GPa}$ and $1200-1600^{\circ} \mathrm{C}$ with run duration of $40 \mathrm{~h}$. Experiments were carried out using a multi-anvil highpressure apparatus of a "split-sphere" type (Pal'yanov et al., 1997). A high-pressure cell (Fig. 1) in the form of tetragonal prism, $21.1 \times 21.1 \times 25.4 \mathrm{~mm}$ in size, was used. The temperature was measured in each experiment using a $\mathrm{PtRh}_{30} / \mathrm{PtRh}_{6}$ thermocouple. Details on the pressure and temperature calibration have been presented elsewhere (Pal'yanov et al., 2002).

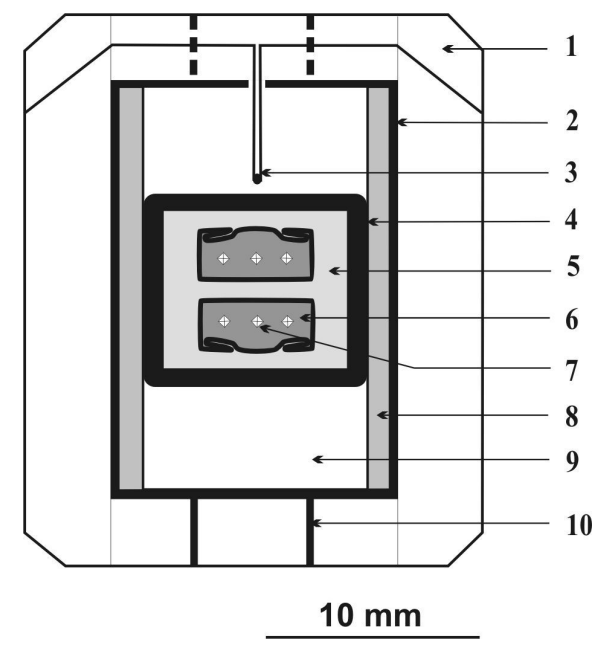

Fig. 1. The high pressure cell: $1-\mathrm{ZrO}_{2}$ container; $2-$ cylindrical graphite heater; $3-\mathrm{PtRh}_{6} / \mathrm{PtRh}_{30}$ thermocouple; 4 - Mo or Fe capsule; 5 - talc; 6 - Pt capsule with sample; 7 - seed diamonds; 8 - MgO; $9-\mathrm{ZrO}_{2} ; 10$ - Mo leads.

In the modern practice of experimental studies at the mantle P-T parameters buffering of the hydrogen fugacity is commonly made using a double-capsule technique (Eugster, 1957). The application of the standard double-capsule methods at temperatures $\geq 1200$ $1400^{\circ} \mathrm{C}$ leads to saturation of the capsule walls with the components of the buffer resulting in the loss of their chemical inertness. For buffering $\mathrm{fH}_{2}$ we have modified the double-capsule method by changing the outer capsule made from a noble metal to thick-wall capsule from molybdenum or iron (Fig. 1). In this case the outer capsule acted as both container and buffer. The outer capsule was loaded with two Pt capsules with samples, which were isolated by talc. At P-T parameters of experiments talc converted to a mixture enstatite + coesite $+\mathrm{H}_{2} \mathrm{O}$. This system was at subsolidus over the entire range of applied temperatures (owing to low oxygen fugacity) ensuring high water activity in fluid phase in the outer capsule. A prolonged life time of the buffer was provided by the low loss of hydrogen through the thick-wall outer capsule, as well as by considerable amount of water forming as a result of talc decomposition.

In order to change $f \mathrm{O}_{2}$ in the samples, while keeping the hydrogen fugacity $\left(\mathrm{H}_{2}{ }^{\mathrm{S}}\right)$ equal to hydrogen fugacity of the buffer $\left(f \mathrm{H}_{2}{ }^{\mathrm{B}}\right)$, we changed the water content in the charges (Whitney, 1972). Only in the case when $\mathrm{H}_{2} \mathrm{O}$ fugacity in the inner capsule is equal to $\mathrm{H}_{2} \mathrm{O}$ fugacity in the outer capsule, the following expression is true: $\mathrm{O}_{2}{ }^{\mathrm{S}}=\mathrm{fO}_{2}{ }^{\mathrm{B}}$.

The assemblage of the capsules was made as follows. Starting materials: distilled water, stearic acid $\left(\mathrm{C}_{16} \mathrm{H}_{36} \mathrm{O}_{2}\right)$, as well as graphite powder (Alfa Aesar, $99.9999 \%$ pure) and three cubo-octahedral diamond seed crystals (size $0.3-0.5 \mathrm{~mm}$ ) were loaded into inner platinum capsules $(5.0 \mathrm{~mm}$ in outer diameter and 0.2 $\mathrm{mm}$ thick of wall). To generate ultra-reduced fluids we used a mixture graphite powder with anthracene $\left(\mathrm{C}_{14} \mathrm{H}_{10}\right)$ or docosane $\left(\mathrm{C}_{22} \mathrm{H}_{46}\right)$. The capsules were placed into a device with liquid nitrogen and sealed by arc welding (the weighing losses under sealing were $<0.5$ $\mathrm{mg}$ ). When the run was accomplished, power was switched off. The quenching rate was about $200^{\circ} \mathrm{C} \mathrm{sec}^{-1}$.

The composition of the $\mathrm{C}-\mathrm{O}-\mathrm{H}$ fluid is commonly calculated using equations of states (EOS) such as the Redlich-Kwong EOS or any of a myriad of EOS developed for fluid calculations. In the present work calculations of the composition of fluid equilibrium with diamond/graphite and estimations of oxygen fugacity in the system were made through minimizing the Gibbs free energy using a "Selektor" computer code (Chudnenko et al., 1995; Karpov et al., 2002). The fluid was treated as the ideal mixture of real gases $\mathrm{CO}_{2}, \mathrm{CO}, \mathrm{CH}_{4}, \mathrm{H}_{2} \mathrm{O}, \mathrm{H}_{2}$, $\mathrm{O}_{2}, \mathrm{C}_{2} \mathrm{H}_{2}, \mathrm{C}_{2} \mathrm{H}_{4}, \mathrm{C}_{2} \mathrm{H}_{6}, \mathrm{C}_{3} \mathrm{H}_{4}, \mathrm{C}_{3} \mathrm{H}_{6}, \mathrm{C}_{3} \mathrm{H}_{8}, \mathrm{C}_{4} \mathrm{H}_{4}, \mathrm{C}_{4} \mathrm{H}_{6}$, $\mathrm{C}_{4} \mathrm{H}_{8}, \mathrm{C}_{4} \mathrm{H}_{10}, \mathrm{C}_{5} \mathrm{H}_{12}$ and $\mathrm{C}_{6} \mathrm{H}_{14}$. Initial thermodynamic parameters of gases (including hydrocarbons) were taken from the g_reid database available in the "Selektor" code, and for diamond and graphite from (Holland and Powell, 1990). Oxygen fugacities for the $\mathrm{Mo} / \mathrm{MoO}_{2}$ 
and $\mathrm{Fe} / \mathrm{FeO}$ (IW) buffers at the studied range of P-T conditions are shown in (Fig. 2). In the calculations of fluid compositions the initial quantities of carbon were always set in the excess to other components of the studied system.

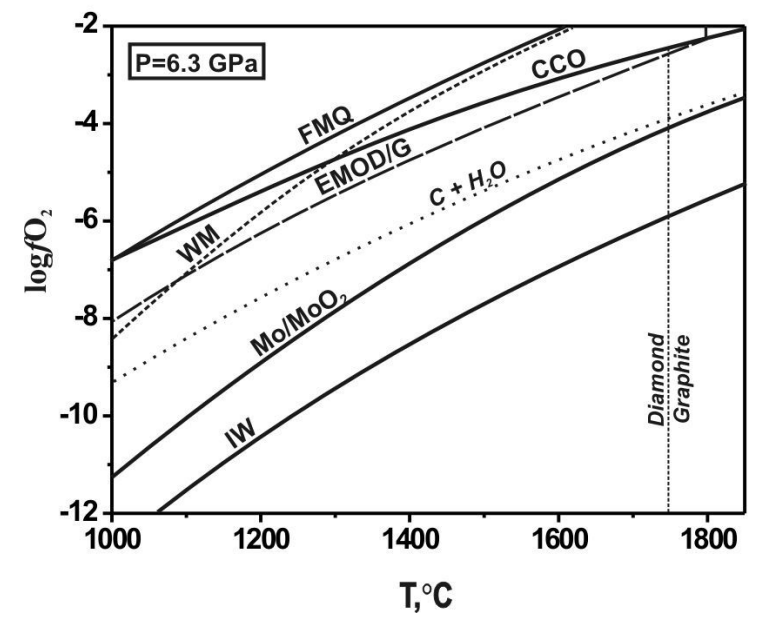

Fig. 2. Oxygen fugacity of buffer reaction as a function of temperature at $6.3 \mathrm{GPa}$.

As it follows from the thermodynamic calculations (Fig. 3) the composition of the $\mathrm{C}-\mathrm{O}-\mathrm{H}$ fluid equilibrium to diamond/graphite at $6.3 \mathrm{GPa}$ and $1400-1600^{\circ} \mathrm{C}$ will vary from $\mathrm{CO}_{2}>>\mathrm{H}_{2} \mathrm{O}$, CO mixtures (at $f \mathrm{O}_{2}$ near $\mathrm{CCO}$ and FMQ buffers) through $\mathrm{H}_{2} \mathrm{O}>>\mathrm{CO}_{2}, \mathrm{CH}_{4}$ mixtures (at $f \mathrm{O}_{2}$ "water maximum", FMQ-2.5) to $\mathrm{CH}_{4}>\mathrm{H}_{2} \mathrm{O}>\mathrm{C}_{2} \mathrm{H}_{6}>$ $\mathrm{H}_{2}$, mixtures (at $f \mathrm{O}_{2}$ near IW, FMQ-4.5). At further decrease in oxygen fugacity, the concentration of $\mathrm{CH}_{4}$ should increase reaching $76 \mathrm{~mol} . \%, \mathrm{H}_{2} \mathrm{O}$ tend to zero, and $\mathrm{H}_{2}$ reach almost 6 mol.\%. At $1200-1600^{\circ} \mathrm{C}$ watermethane fluid equilibrium with the $\mathrm{Mo} / \mathrm{MoO}_{2}$ and $\mathrm{Fe} / \mathrm{FeO}$ buffers contained $24-6 \mathrm{wt} \%$ and $75-60 \mathrm{wt} \%$ of methane, respectively.

In the $\mathrm{H}_{2} \mathrm{O}-\mathrm{C}$ system at $1600^{\circ} \mathrm{C}$ and run duration of $40 \mathrm{~h}$ the degree of graphite-to-diamond conversion $(\alpha)$ was $100 \%$ (Fig. 4). At the same parameters in watermethane fluid $\alpha$ decreased to $50 \%$, and metastable graphite crystallized. With temperature decrease to $1400^{\circ} \mathrm{C}, \alpha$ sharply decreases to $<1 \%$. In fluid buffered IW, nucleation of individual spontaneous diamonds was established at $1600^{\circ} \mathrm{C}$. The main phase crystallized was metastable graphite. At $1200-1400^{\circ} \mathrm{C}$ diamond nucleation was not found and the rate of diamond growth on seeds was very low.

In the samples containing ultra reduced fluid with the ratio $\mathrm{H} / \mathrm{O}>4$, spontaneous diamond nucleation was not observed. In experiments with long duration specific dendrite diamond crystals were found on the walls of the Pt capsules. No diamond growth on the seed crystals was observed. In some cases, very thin diamond layers were probably formed on the seed crystals, but the resolution of the optical microscopes was not sufficient for unambiguous identification of the diamond growth. Metastable graphite crystallized in the form of flaky crystals. The amount of the newly-formed graphite did not depend on the system composition, but on the

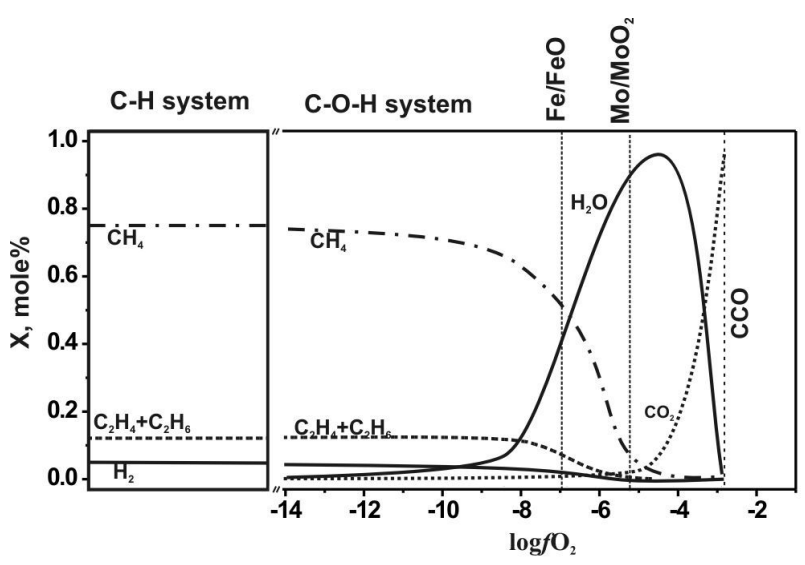

Fig. 3. Thermodynamic calculations of the $\mathrm{C}-\mathrm{O}-\mathrm{H}$ fluid compositions at $6.3 \mathrm{GPa}$ and $1600^{\circ} \mathrm{C}$ performed using a "Selector" computer code.

content of fluid phase. In experiments with only graphite charges no flaky graphite crystals were found. In the samples with high amount of fluid generating substances, graphite druses were revealed on the capsule walls and diamond seed crystals.

Thus, the highest catalytic ability of fluid with respect to diamond formation at studied T- $\mathrm{fO}_{2}$ parameters was established at $1600^{\circ} \mathrm{C}$ and oxygen fugacity $\mathrm{FMQ}-$ $1 \div-2.5 \log$ units (Fig. 4). In the $\mathrm{Mo} / \mathrm{MoO}_{2}$ buffered fluid $\left(\mathrm{CH}_{4} \approx 10 \mathrm{wt} . \%\right)$ the degree of the graphite-to-diamond transformation is considerably lower than in the $\mathrm{H}_{2} \mathrm{O}-\mathrm{C}$ system. In the IW buffered fluid (FMQ-5.5 log units, $\mathrm{CH}_{4} \approx 65$ wt.\%) diamond nucleation was not observed. Only very slight diamond growth was fixed on the seeds crystals.

In the $\mathrm{Mg}_{2} \mathrm{SiO}_{4}-\mathrm{H}_{2} \mathrm{O}-\mathrm{CH}_{4}-\mathrm{C}$ system at temperatures of $1400-1600^{\circ} \mathrm{C}$, and $f \mathrm{O}_{2}$ corresponding to $\mathrm{Mo} / \mathrm{MoO}_{2}$ buffer, liquidus forsterite co-exists with the saturated fluid melt. In this forsterite melt at $1600^{\circ} \mathrm{C}$ individual spontaneous diamond crystals were formed on the surface of $\mathrm{Pt}$ capsules, and at $1400^{\circ} \mathrm{C}$ only diamond growth on seeds was established. In experiments with IW buffer at $1200-1600^{\circ} \mathrm{C}$, system did not melt and was represented by a fluid-forsterite subsolidus association. In the methane-rich fluid diamond growth on seeds was found only at $1600^{\circ} \mathrm{C}$. At $1200-1400^{\circ} \mathrm{C}$ no diamond formation was established.

In the studied range of conditions, diamond crystallization has maximum intensity in aqueous fluids (Palyanov et al., 2007; Sokol, Palyanov, 2008). However, with increasing depth, concentration of methane in equilibrium $\mathrm{H}_{2} \mathrm{O}$-rich fluid is likely to increase (Woodland, Koch, 2003). This probably leads to, on the one hand, extending the stability field of subsolidus fluid phase due to increase in the melting temperature of rocks, and, on the other hand, to decreasing intensity of diamond formation. At low methane concentrations fluid is rather effective media of diamond crystallization. With an increase in $\mathrm{CH}_{4}$ concentration in fluid, diamond crystallization is virtually terminated. This may account for the 
rarity of inclusions of hydrocarbons in natural diamonds (Melton, Giardini, 1974; Tomilenko et al., 2001).

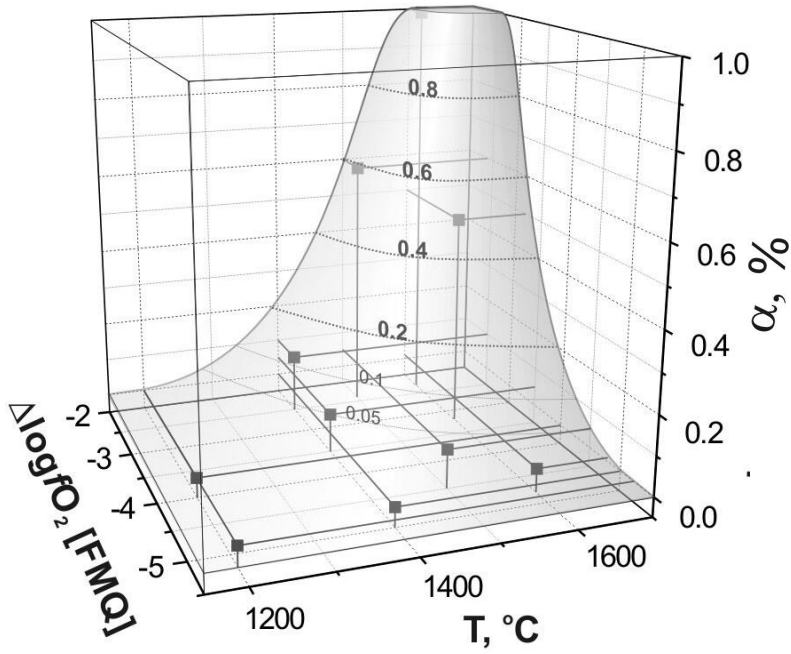

Fig. 4. Degree of the graphite-to-diamond transformation $(\alpha)$ in the C-O-H fluid as a function of $f \mathrm{O}_{2}$ and temperature at $\mathrm{P}=6.3 \mathrm{GPa}$ and $\tau=40 \mathrm{hrs}$.

Due to buoyancy, such fluids could migrate upwards through cratonic peridotite into less reduced environments and generate multiple redox-fronts (Taylor, Green, 1988). The oxidation of hydrogen and hydrocarbons within the range of the multiple redox-fronts would result in the formation of an essentially aqueous fluid and drastic decrease in carbon content in it. At $f \mathrm{O}_{2}$ close to the "water maximum" (Fig. 3) the fluid consists of water for more than $95 \mathrm{~mol} \%$. Consequently, almost all carbon, which was contained in methane and hydrocarbons, upon oxidation would be released as $\mathrm{C}^{0}$ and would be exhausted for saturating $\mathrm{H}_{2} \mathrm{O}$-rich fluid with elemental carbon and afterwards for diamond crystallization. The nucleation of diamond and its subsequent growth in the aqueous fluid, containing variable amounts of silicate components, carbonates and alkalis proceed with relatively high rates (Yamaoka et al., 2000; Sokol et al., 2001; Palyanov et al., 2007; Sokol, Palyanov, 2008). In this case, inclusions entrapped in diamond would have an oxidized composition (Navon, 1999).

This work was supported by the Russian Foundation for Basic Research (grant 07-05-00642) and Foundation for National Science Promotion.

\section{References}

Chudnenko, K.V., Karpov, I.K., Bychinski, V.A., Kulik, D.A., 1995. Current status of the SELEKTOR soft package. In: Kharaka, Y.K., Chudaev, O.V. (Eds.), Proceedings of the 8th International Symp. on Water-Rock Interaction, Vladivostok, Russia. Balkema, Rotterdam, p. 725-727.

Eugster H.P., 1957. Heterogeneous reactions involving oxidation and reduction at high pressures and temperatures. J. Chem. Phys., 26, 1760-1761.

Holland T.J.B., Powell L., 1990. An enlarged and updated internally consistent thermodynamic dataset with uncertainties and correlations: $\mathrm{K}_{2} \mathrm{O}-\mathrm{Na}_{2} \mathrm{O}-\mathrm{CaO}-\mathrm{MgO}-\mathrm{FeO}-$
$\mathrm{Fe}_{2} \mathrm{O}_{3}-\mathrm{Al}_{2} \mathrm{O}_{3}-\mathrm{TiO}_{2}-\mathrm{SiO}_{2}-\mathrm{C}-\mathrm{H}_{2}-\mathrm{O}_{2}$ J. Metamorphic Geol., $8,89-124$.

Karpov, I.K., Chudenko, K.V., Kulik, D.A., Bychinskii, V.A., 2002. The convex programming minimization of five thermodynamic potentials other that Gibbs energy in geochemical modeling. Am. J. Sci. 302, 281-311.

Luth R.W., 1999. Carbon and carbonates in the mantle. Mantle petrology: Field observation and high pressure experimentation: a tribute to Francis R. (Joe) Boyd / Ed. Fei Y., Bertka C. M., Mysen B. O. The Geochemical Society, Special Publication, № 6. p. 297-316.

Melton C.E., Giardiny A.A., 1974. The composition and significance of gas realized from natural diamonds from Africa and Brazile. Amer.Miner., 59, 775-782.

Navon O., 1999. Diamond formation in the Earth's mantle. In: Gurney JJ, Gurney JL, Pascoe MD, Richadson SH (eds) VII International Kimberlite conference, Red roof design, Cape Town, p. 584-604.

Pal'yanov Yu.N., Khokhryakov A.F., Borzdov Yu.M., Sokol A.G. et al., 1997. Growth conditions and real structure of synthetic diamond crystals. Geol Geofiz., 38, 920-945.

Pal'yanov, Yu.N., Sokol, A.G., Borzdov, Yu.M., Khokhryakov, A.F., 2002. Fluid-bearing alkaline carbonate melts as the medium for the formation of diamond in the Earth's mantle: an experimental study. Lithos, 60, 145-159.

Pal'yanov, Yu.N., Shatsky, V.S., Sokol, A.G., Sobolev N.V., 2007. The role of mantle ultrapotassic fluids in diamond formation. PNAS, 104, 9122-9127.

Rohrbach A., Ballhaus C., Golla-Schindler U., Ulmer P., Kamenetsky V.S., Kuzmin D.V., 2007. Metal saturation in the upper mantle. Nature, 449, 456-458.

Sokol, A.G., Pal'yanov, Yu.N., Pal'yanova, G.A., Khokhryakov, A.F., Borzdov, Yu.M., 2001. Diamond and graphite crystallization from $\mathrm{COH}$ fluids under high pressure and high temperature conditions. Diamond Relat. Mater., 10, 2131-2136.

Sokol, A.G., Pal'yanov, Yu.N., 2008. Diamond formation in the system $\mathrm{MgO}-\mathrm{SiO}_{2}-\mathrm{H}_{2} \mathrm{O}-\mathrm{C}$ at $7.5 \mathrm{GPa}$ and $1600^{\circ} \mathrm{C}$. Contrib. Mineral. Petrol., 155, 33-43.

Taylor W.R., Green D.H., 1988. Measurement of reduced peridotite-C-O-H solidus and implications for redox melting of the mantle. Nature, 332, 349-352

Tomilenko A.A.; Ragozin A.L.; Shatskii V.S.; Shebanin A.P., 2001.Variation in the fluid phase composition in the process of natural diamond crystallization. Dokl Earth Sci., 379, 571-574.

Whitney J.A., 1972. The effect of reduced $\mathrm{H}_{2} \mathrm{O}$ fugacity on the buffering of oxygen fugacity in hydrothermal experiments Am. Miner., 57, 1902-1908.

Woodland A.B., Koch M., 2003. Variation in oxygen fugacity ith depth in the upper mantle beneath the Kaapvaal craton, Southern Africa. Earth Plan. Sci. Lett., 214, 295-310.

Yamaoka S., Kumar M.S.D., Akaishi M., Kanda H., 2000. Reaction between carbon and water under diamond-stable high-pressure and high-temperature conditions. Diamond Relat. Mater., 10, 1480-1486. 